\title{
RECENZJE
}

\author{
Bodil Petersson, Lars Erik Narmo (eds.), Experimental Archaeology. \\ Between Enlightenment and Experience, \\ Acta Archaeologica Lundensia Series in $8^{\circ}$, No 62, \\ Department of Archaeology and Ancient History, Lund 2011
}

Bodil Petersson jest szwedzką archeolożką, której ostatnie prace wiążą się z szeroko rozumianą archeologią publiczną. Z kolei Lars Erik Narmo jest norweskim badaczem, specjalizującym się w archeologii doświadczalnej.

Prezentowana książka jest pokłosiem projektu badawczego „Experimental Archaeology. Between Enlightenment and Experience". We wprowadzeniu (Introduction) B. Petersson zapoznaje czytelnika z historią, przebiegiem i celami projektu. W 2008 r. miały miejsce warsztaty w Lofoten, z kolei w 2009 r. odbyły się spotkania w Lund i Kopenhadze. Celem projektu było zapoczątkowanie bliższej współpracy między archeologami zajmującymi się archeologią doświadczalną w Skandynawii, przy czym chodziło o połączenie różnych środowisk: akademickich z tymi pracującymi w muzeach na otwartym powietrzu. Jak jasno wskazuje tytuł książki, autorzy chcieli pokazać wieloaspektowość współczesnych badań w ramach archeologii doświadczalnej. Archeologia ta bowiem, w zamyśle autorów, jest subdyscypliną archeologii, ale jest również praktyką społeczną, sposobem dialogu, interakcji ze społeczeństwem oraz specyficzną formą „doświadczania przeszłości”. Właśnie ten aspekt projektu trzeba szczególnie uwypuklić jako istotny.

W drugim rozdziale książki (A Journey in Time) B. Petersson i L.E. Narmo kreślą historię skandynawskiej archeologii doświadczalnej na szerszym europejskim tle. Twierdzą, iż do tej pory archeologia doświadczalna kładła szczególnie nacisk na studia technologiczne (np. wypał naczyń ceramicznych), opierając się na założeniach „nowej archeologii” (hipotetyczno-dedukcyjne wnioskowanie). Autorzy nie negują takich działań. Argumentują jednak, że jest to podejście ograniczające samą archeologię. Im z kolei chodzi o jej poszerzenie - by dążyła nie tylko do bycia nauką w duchu pozytywistycznym, lecz także częścią współczesnej humanistyki. Dowodzą, że potrzebna jest - jak to ujmują - humanistic experimental archaeology. Ważny ma być w takiej archeologii nie tylko sam proces eksperymentu, ale równie istotną jego częścią są aktorzy, jego uczestnicy: osoby przeprowadzające dany eksperyment, widzowie, turyści itd. Zwrócenie bliższej uwagi na ten aspekt może poszerzyć i otworzyć nowe tory dla współczesnej archeologii doświadczalnej.

Następny rozdział jest autorstwa Påvela Nicklassona (A Time for Poets: Experimental Archaeology in Götiska Förbundet). Szwedzki archeolog przyjmuje bardzo szerokie rozu- 
mienie eksperymentu $\mathrm{w}$ archeologii: eksperymentu myślowego (thought experiment). Omawia on pewne szwedzkie towarzystwo miłośników starożytności (Götiska Förbundet) oraz zawiłe drogi wyłaniania się archeologii jako nauki akademickiej w tym czasie. W tym okresie było kilka sposobów myślenia, doświadczania przeszłości. I w jednym z nich miała swój początek akademicka archeologia.

$\mathrm{O}$ działaniach związanych $\mathrm{z}$ archeologią doświadczalną na tle europejskim pisze następnie Roeland Paardekooper (Experimental Activities. A European Perspective). Zauważa on, że pod terminem archeologii doświadczalnej rozumie się często rzeczy, które nie są ani archeologią, ani eksperymentem (np. rekonstrukcje budynków, lekcje tzw. żywej archeologii). W jego zamierzeniu archeologia doświadczalna ma nadal być kontrolowanym i naśladującym przeszłe zjawiska eksperymentem. Autor podkreśla potencjał popularnych w Europie muzeów na otwartym powietrzu, które powinny stanowić naturalny kontekst dla eksperymentów naukowych. Podkreśla również potrzebę bardziej formalnego zorganizowania środowiska badaczy zajmujących się archeologią doświadczalną.

Tine Schenck z kolei w swoim tekście (Experimenting with the Unknown) przypomina toczącą się dyskusję w ramach archeologii doświadczalnej między kontrolowanym eksperymentem a aktualizmem w jej ramach. Każdy eksperyment archeologiczny ma mieć elementy, na które archeolog nie ma wpływu. Autor mówi również, że udany eksperyment to taki, który pozwala dowiedzieć się czegoś nowego. Twierdzenie to omawia na przykładzie próby beznaczyniowej produkcji dziegciu. Eksperyment ten, mierzony standardami wyznaczonymi przez „nową archeologię”, nie jest działaniem naukowym. Jednak gdy patrzy się na niego dzięki zdobytej nowej wiedzy, z perspektywy hermeneutyki, odczytywania nowych treści, to ta próba może zostać uznana za naukową. Warto podkreślić, że autor rozwija ten aspekt archeologii doświadczalnej związanej nie tyle z - używając słów redaktorów książki - enlightment, ile raczej z experience.

Lotte Eigeland w rozdziale State or Status Quo? Experimental Archaeology in East Norwegian Stone Age Research również patrzy na archeologię doświadczalną z perspektywy osoby czynnie zajmującej się nią. Omawia historię badań nad epoką kamienia. Podkreśla również problemy związane z faktem, iż niewielu archeologów zajmuje się w Norwegii tą tematyką. Co istotne, uwypukla też znaczenie lokalnych badań. Na przykład: w związku z brakiem dobrej jakości krzemienia w północnej Skandynawii ludzie w epoce kamienia musieli używać jego substytutów. A zatem badania prowadzone na dobrej jakości krzemieniu (np. jak to robią badacze z Danii i Francji) nie zdają tutaj egzaminu. Ponownie pada głos o potencjale muzeów na otwartym powietrzu czy też living history centres dla rozwoju i promocji samej archeologii.

Dwa kolejne teksty są autorstwa duńskich archeolożek: Henriette Lyngstrøm (Teaching Experimental Archaeology at the University of Copenhagen) oraz Marianne Rasmussen (Under the Same Roof. Experimental Research and Interpretation with Examples from the Construction of House Models). Pierwsza z nich opisuje historię rozwoju archeologii doświadczalnej na Uniwersytecie w Kopenhadze oraz relacje wiążące ją z HistoricalExperimental Centre w Lejre. Druga z kolei opisuje inicjatywy badawcze podejmowane przez ośrodek w Lejre. Podkreśla jego rolę w rozwoju i promowaniu archeologii doświadczalnej nie tylko w Skandynawii. Lejre jest jednym z najważniejszych miejsc europejskiej archeologii doświadczalnej w ogóle. M. Rasmussen zauważa wyraźnie kierunek zmian, jakie 
mają miejsce w Lejre. Kiedyś był to ośrodek badawczy, a obecnie stał się parkiem tematycznym. Nawet nazwa miejsca uległa zmianie. Teraz to jest: „Land of Legends, Lejre” (Kraina legend). Ma to swoje pozytywne i negatywne aspekty, które autorka przybliża.

Interesujące uwagi teoretyczne w kolejnym rozdziale formułuje Anna S. Beck (Working in the Borderland of Experimental Archaeology. On Theoretical Perspectives in Recent Experimental Work). Autorka twierdzi, że archeologia doświadczalna nie doczekała się jeszcze generalnej dyskusji dotyczącej zagadnienia: archeologia procesualna versus archeologia postprocesualna. Nadal doświadczenia archeologiczne mają być ocenianie przez pryzmat „paradygmatu” procesualnego. Postprocesualna archeologia doświadczalna, tzw. contextual approaches, stawia sobie z kolei inne cele, stosuje inne metody, a zatem jej wyniki powinny również być oceniane z innej perspektywy. Niewątpliwym atutem tekstu jest to, że autorka swoje rozważania teoretyczne oparła na trzech eksperymentach, które przeprowadziła w Lejre. Tekst jest świadectwem drastycznych zmian, które zachodzą w europejskiej archeologii doświadczalnej.

Współredaktor książki, L.E. Narmo, w rozdziale The Unexpected również pisze o ograniczeniach pozytywistycznie widzianej archeologii doświadczalnej. Każdy eksperyment niesie ze sobą właśnie unexpected, nieoczekiwane rezultaty. Autor nie podbudowuje swej obserwacji wystarczającą dyskusją teoretyczną, ale argumentuje na jej rzecz, opierając się na własnych badaniach, które prowadził w Lofotr Viking Museum.

Kjel Knutsson od wielu lat zajmuje się archeologią doświadczalną. Swój tekst poświęcił jej historii, rozwojowi na Uniwersytecie w Uppsali ( $A$ View from the Inside. Experimental Archaeology at Uppsala University 1971-2008). Ukazuje on m.in., jak ważna dla jej rozwoju jest współpraca uniwersytetu z muzeami na otwartym powietrzu. Również zauważa, że ogólne debaty teoretyczne wpływają na zainteresowanie samą archeologią doświadczalną. W latach 80., 90. XX w. wielu studentów, doktorantów zajmowało się tą problematyką. Ostatnimi czasy, wraz z szerszą debatą nad archeologią postprocesualną, zainteresowanie eksperymentami archeologicznymi spadło i zostało przedefiniowane. Młodzi badacze nie skupiają się na technologii produkcji, np. narzędzi kamiennych. Raczej interesują ich polityczne, etyczne, kulturowe zjawiska powiązane z samą archeologią doświadczalną.

Przykładem takiego poszerzenia archeologii doświadczalnej jest tekst Gørill Nilsen (Doing Archaeological Experiments in an Ethnic Context. Experimental Archaeology or Experiential Activities?). Autorka wychodzi od zwrócenia uwagi na ograniczenia tradycyjnie widzianej archeologii doświadczalnej. Ma się ona nie sprawdzać w wieloetnicznym społeczeństwie norweskim. Rozważanymi przykładami są eksperymenty bazujące na archeologicznych znaleziskach (np. pozostałościach domostw, jam do wytwarzania tranu), łączonych z ludem Sami. Jak podkreśla, eksperymenty archeologiczne są ważne nie tylko w świecie naukowym, lecz także mają swe implikacje dla lokalnej społeczności. Te dwa wymiary powinny się uzupełniać, a na pewno siebie nie wykluczać.

Ostatni tekst jest autorstwa Larsa F. Stenvika (Experiments with Iron Production in Trøndelag). Tekst ma charakter sprawozdania z prowadzonych eksperymentów. Autor przedstawia w nim swoje doświadczenia z próbami wytopu żelaza w środkowej Norwegii.

Podsumowując: redaktorzy tomu zebrali wiele doświadczeń i perspektyw patrzenia na archeologię doświadczalną w Skandynawii. Zaprezentowali jej historię, ale, co chyba nawet ważniejsze, pokazali jej złożoność i przyszłe trendy, które powinny być rozwijane. Praca jest 
wydana na dobrej jakości papierze kredowym, z wieloma kolorowymi ilustracjami pokazującymi wybrane eksperymenty archeologiczne, również napisana jasnym językiem. Książkę należy polecić osobom, które próbują uczyć archeologii doświadczalnej, jak również studentom zainteresowanym tą tematyką (szerzej: archeologią publiczną). Również opis przeprowadzonych eksperymentów może zainteresować osoby niezwiązane bezpośrednio $\mathrm{z}$ archeologią, ale zafascynowane jej wieloma wymiarami (np. środowisko odtwórstwa historycznego).

I ostatnia uwaga: za ironię losu trzeba uznać nieszczęśliwe - jak się wydawało przez ostatnie lata - Marii Miśkiewicz tłumaczenie Experimental Archaeology Johna Colesa jako Archeologii doświadczalnej. W dyskursie archeologii anglosaskiej istnieją bowiem dwa różne wyrażenia w tym kontekście. Experimental archaeology (w tłumaczeniu dosłownym: ,archeologia eksperymentalna") widziana była jako subdyscyplina archeologii, przeprowadzająca naukowe eksperymenty. Natomiast te zjawiska, które nie spełniały pozytywistycznych wymagań wyznaczonych przez „nową archeologię, były nieco pogardliwie określane mianem experiential archaeology, archeologią doświadczalną. Jak pokazuje jednak omawiana książka, istnieje coraz większa potrzeba uwzględnienia „subiektywnych” elementów prowadzonych eksperymentów archeologicznych, doświadczeń ludzi je przeprowadzających, oraz społeczeństwa, które chętnie przygląda się (i czasem aktywnie uczestniczy) w archeologicznych badaniach. Słowem, archeologia doświadczalna zmierza do tego, by była ona jeszcze bardziej „doświadczalna”, społeczna niż ,eksperymentalna”, stricte naukowa w sensie pozytywistycznym. I to zostało w pewien niezamierzony sposób założone w przekładzie M. Miśkiewicz.

Dawid Kobiatka

Instytut Prahistorii, Uniwersytet im. A. Mickiewicza

ul. Św. Marcin 78, 61-809 Poznań, Poland

\section{William S. Hanson, Ioana A. Oltean (eds.), Archaeology From Historical Aerial and Satellite Archives, Springer, New York-London 2013}

Zasoby historycznych zdjęć lotniczych wykonanych w celach militarnych lub kartograficznych stosunkowo rzadko są przedmiotem zainteresowań archeologów. We współczesnych pracach, omawiających zastosowanie fotografii lotniczych, badacze skupiają się przede wszystkim na uzyskiwaniu i wykonywaniu nowych zdjęć, pomijając bogate źródła archiwalne lub rzadko o nich wspominając (s. 5). Lukę tę stara się wypełnić książka Archaeology from Historical Aerial and Satellite Archives pod redakcją Williama S. Hansona i Ioany A. Oltean. Jest to praca poświęcona potencjałowi, jaki drzemie w odtajnionych archiwach konfliktów zbrojnych XX w. Jak deklarują na wstępie redaktorzy, celem książki jest zwrócenie uwagi archeologów na istnienie, zakres oraz możliwości poznawcze, jakie oferują archiwalne zdjęcia lotnicze i zobrazowania satelitarne, oraz zachęcenie badaczy do wykorzystywania tych materiałów w studiach nad krajobrazem kulturowym (s. 9). 